\title{
Optimization of Total Flavonoids Extraction from Coreopsis tinctoria Nutt. by Response Surface Methodology
}

DOI: $10.15255 /$ KUI.2013.027

KUI-24/2014

Original scientific paper

Received August 17, 2013

Accepted December 17, 2013

\author{
X. F. Liu, L. Liu, Y. G. Wang, ${ }^{*}$ F. F. Leng, \\ S. W. Wang, and Y. C. Li
}

School of Life Science and Engineering, Lanzhou University of Technology,

730050 Lanzhou, PR China

\begin{abstract}
Response surface methodology (RSM) was applied to predict optimum conditions for extraction of flavonoid from Coreopsis tinctoria Nutt. A central composite design (CCD) was used to monitor the effect of extraction temperature, extraction time, and water-to-material ratio on yield of total flavonoids. The optimal extraction conditions were obtained as water-to-material ratio of $55 \mathrm{ml}$ $\mathrm{g}^{-1}$, extraction temperature of $80{ }^{\circ} \mathrm{C}$ and extraction time of 70 minutes. Under these conditions, the average total flavonoids yield, according to the mass of raw material, was $9.0 \pm 0.6 \%$, which corresponds to the predicted value of $8.9 \%$. Thus, the extraction method was applied successfully to extract total flavonoids from C. tinctoria.
\end{abstract}

Key words: Coreopsis tinctoria Nutt., flavonoid, reflux extraction, response surface methodology

\section{Introduction}

Numerous studies have shown that flavonoids have many biological activities, such as antibacterial, antiviral, anticancer and antioxidant. ${ }^{1,2,3}$ Flavonoids, consisting of flavones, flavanone, flavanols, flavonols, and flavanonols, comprise a large group of secondary metabolites in plants, ${ }^{4,5,6} \mathrm{e} . \mathrm{g}$. vegetables, fruits, flowers, roots, stems and herbs. ${ }^{7,8,9}$ Present studies have shown that flavonoids from Coreopsis tinctoria Nutt. have a significant amounts of bioactive components. ${ }^{6,10,11}$

C. tinctoria is an annual forb widespread in Canada, Northeast Mexico, much of the United States, especially the Great Plains and Southern states, and is often called "calliopsis" by the native residents. ${ }^{6,10} \mathrm{C}$. tinctoria plants attain heights of 30 to $100 \mathrm{~cm}$. The leaves are pinnately divided, glabrous, and tending to thin out at the top of the plant where numerous 2.5 to $3.75 \mathrm{~cm}$ flowers sit atop slender stems. The flavonoid-rich flowers are brilliant yellow with maroon or brown centres of various size. ${ }^{6}$

Water extraction technology of flavonoid from C. tinctoria was studied by response surface methodology (RSM). RSM, first introduced by Box and Wilson, is a very useful tool for this purpose. As a package of statistical and mathematical techniques employed for developing, improving, and optimizing processes, RSM could be used effectively to evaluate the effects of multiple factors and their interaction on one or more response variables. ${ }^{12,13,14,15,16}$ In this study, RSM was used to optimize the extraction conditions

\footnotetext{
"Corresponding author: Prof. Yonggang Wang
}

e-mail: 18009400938@163.com (water-to-raw-material ratio, extraction temperature, and extraction time). The extraction efficiency was validated by RSM.

\section{Material and methods}

\section{Plant material and chemicals}

Coreopsis tinctoria Nutt. (Asteraceae) was collected in August 2011 in Hetian County (Xijiang Uygur Autonomous Region, PR China) and identified by Prof. Lin Yang (School of Life Sciences and Engineering, Lanzhou University of Technology). Five hundred grams of C. tinctoria was dried, ground to powder, and sieved through a 40-mesh screen.

All analytical grade solvents came from Beijing Solarbio Co., Ltd. (Beijing, PR China), and standard of rutin (> $98 \%$ ) was obtained from Sangon Biotech (Shanghai) Co., Ltd. (Shanghai, PR China).

\section{Extraction of flavonoids and determination of extraction yield}

The dried flower samples (2.0 g) were extracted for flavonoids by reflux extraction at different temperatures $\left(25^{\circ} \mathrm{C}\right.$ to $95{ }^{\circ} \mathrm{C}$ ) with a water-to-raw-material ratio $\left(\mathrm{ml} \mathrm{g}^{-1}\right.$ ) (ranging from $1: 6$ to $1: 21$ ) for a given extraction time (ranging from 0.5 to $3.0 \mathrm{~h})$. The flavanone extracts were added to a defined volume of water $(100 \mathrm{ml})$ and filtered. The concentration of flavonoid extracted from C. tinctoria was measured according to the method described by Wu et al. ${ }^{17}$ The absorbance of solution was measured at $510 \mathrm{~nm}$. The concentration of flavonoids in this sample was calculated according to calibration curve of rutin. The flavonoids yield, $Y$, accord- 
ing to the mass of raw material, $m$, was calculated as follows:

$$
Y=\frac{\gamma N V}{m}
$$

where $y$ is the mass concentration of flavonoid calculated by the calibrated regression equation, $N$ is the dilution factor, and $V$ is the total volume of extraction solution.

\section{Experimental design}

In this study, the single factor experimental was employed to guide the preliminary range of variables including $X_{1}$ (water-to-raw-material ratio), $X_{2}$ (extraction temperature), and $X_{3}$ (extraction time). A central composite design (CCD) was used to investigate the effects of three independent variables, $X_{1}, X_{2}$, and $X_{3}$ on the yield of flavonoids $(Y)$. The independent variables were coded at three levels $(-1,0$, and 1 ), and the complete design consisted of 20 experimental points, including six replications of the centre points (all variables were coded as zero). In detail, $X_{1}\left(45,55,65 \mathrm{ml} \mathrm{g}^{-1}\right)$, $X_{2}\left(75,80,85^{\circ} \mathrm{C}\right)$, and $X_{3}(45,60,75 \mathrm{~min})$ were investigated, respectively.

\section{Statistical analysis}

Experimental data showed that the response variables were fitted to a quadratic polynomial model. The general form of the quadratic polynomial model was as follows

$$
y=\beta_{0}+\sum_{i=1}^{3} \beta_{i} x_{i}+\sum_{i=1}^{3} \beta_{i i} x_{i}^{2}+\sum_{i<j=1}^{3} \beta_{i j} x_{i} x_{j}
$$

where $y$ is the measured response associated with each factor-level combination; $\beta_{0}, \beta_{i j} \beta_{i i}$ and $\beta_{i j}$ are the regression coefficients for intercept, linear, quadratic and interaction terms, respectively; $x_{i}$ and $x_{j}$ are the coded independent variables. DesignExpert Software (Trial Version 7.1.6., Stat-Ease Inc., Minneapolis, MN, USA) was used to estimate the response of each set of experimental design and optimized conditions. The fit of the quadratic polynomial model was inspected by the regression coefficient $R^{2}$. F-value and $p$-value were used to check the significance of the regression coefficient.

\section{Results and discussion}

\section{Effect of extraction temperature} on extraction yield of flavonoids

With a fixed water-to-raw-material ratio of $50 \mathrm{ml} \mathrm{g}^{-1}$, extraction time of 60 minutes, the extraction efficiency of flavonoids with the increase in extraction temperature will increase gradually and tend to be gentle (Fig. 1a), which is due to the gradual increase in the molecular diffusion rate with temperature. However, flavonoids are heat-sensitive and excessive temperatures will cause degradation. Low temperature extraction will save energy, therefore $80{ }^{\circ} \mathrm{C}$ was selected as the optimal extraction temperature.

\section{Effect of the water-to-raw-material ratio on the yield of flavonoids}

At a temperature of $70{ }^{\circ} \mathrm{C}$ and extraction time of $60 \mathrm{~min}$ utes, the extraction efficiency will increase gradually with the increase in the water-to-raw-material ratio (as shown in Fig. 1b). At water-to-raw-material ratio of more than $55 \mathrm{ml} \mathrm{g}^{-1}$, the extraction yield increases very slowly and steadily. Thus, the value of $55 \mathrm{mlg}^{-1}$ was chosen as optimal.

\section{Effect of extraction time on extraction yield of flavonoids}

By setting the water-to-raw-material ratio at $50 \mathrm{ml} \mathrm{g}^{-1}$ and extraction temperature $70{ }^{\circ} \mathrm{C}$, the extraction efficiency increased with the extension of extraction time and tended to stabilize (Fig. 1c). The extraction efficiency was highest at 60 minutes.

\section{Optimization of flavonoid extraction conditions}

According to the values obtained in the single factor experiment and method of CCD experiment, RSM was applied to optimize the extraction conditions of flavanoids from $C$. tinctoria. Table 1 shows the experiment design matrix with the response values obtained. Multiple regression analysis of
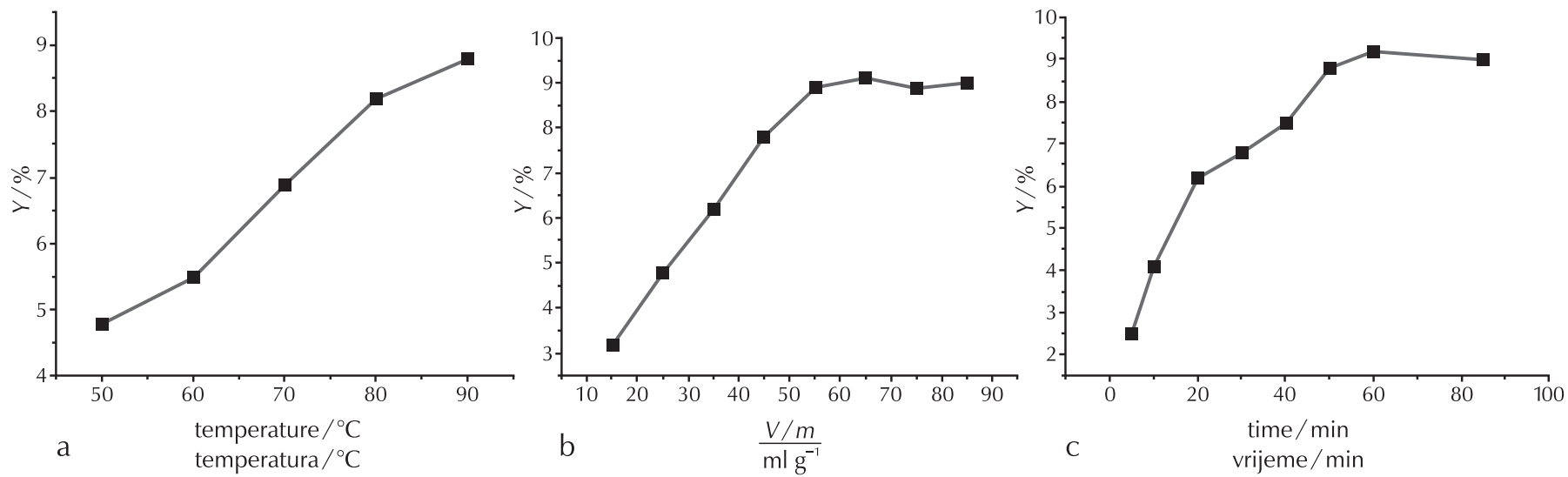

Fig. 1 - Effect of different parameters on the yield of flavonoid extraction (a - extraction temperature, $b$ - water-to-raw-material ratio, $c$ - extraction time)

SIika 1 - Utjecaj različitih parametara na iskorištenje ekstrakcije flavonoida (a - temperatura, b - omjer vode $i$ sirovog materijala, $c$ - vrijeme) 
the experimental data yielded the following second-order polynomial equation:

$$
\begin{aligned}
Y / \%= & -102.91064+0.22740 X_{1}+2.40285 X_{2}+ \\
& +0.23775 X_{3}+0.00137500 X_{1} X_{2}- \\
& -0.000591667 X_{1} X_{3}-0.000983333 X_{2} X_{3}- \\
& -0.00263636 X_{1}^{2}-0.014945 X_{2}^{2}- \\
& -0.000860606 X_{3}^{2}
\end{aligned}
$$

The ANOVA for the fitted quadratic polynomial model of flavanoid extraction is shown in Table 2. The $F$-value of 33.43 with a low probability $p$-value indicated high significance of the model. The coefficient of determination $\left(R^{2}\right)$ of 0.9678 was the proportion of variability in the data explained or accounted for by the model. The significance of each coefficient was determined using $F$-value and $p$-value. The results are given in Table 3. It could be seen that the independent variables $\left(X_{2} X_{3}\right)$, and the quadratic terms $\left(X_{1}{ }^{2}\right.$, $\left.X_{2}{ }^{2}\right)$ significantly affected the yield of flavanoids $(p<0.01)$. The other independent variables $\left(X_{1}\right)$ and quadratic terms $\left(X_{3}{ }^{2}\right)$ were significant also $(p<0.05)$. The two-variable interaction $X_{1} X_{2}, X_{2} X_{3}, X_{1} X_{3}$ had no significant influence $(p>0.1)$ on the extraction yield of flavanoids. Based on linear and quadratic coefficients, it was concluded that the order of factors influencing the response value of the extraction yield

\begin{tabular}{|c|c|c|c|c|}
\hline & $\begin{array}{c}X_{1} \\
\text { temperature } /{ }^{\circ} \mathrm{C} \\
\text { temperatura } /{ }^{\circ} \mathrm{C}\end{array}$ & $\begin{array}{c}X_{2} \\
\text { time/min } \\
\text { vrijeme/min }\end{array}$ & $\begin{array}{c}X_{3} \\
(V / m) / \mathrm{ml} \mathrm{g}^{-1}\end{array}$ & $Y / \%$ \\
\hline 1 & 45 & 75 & 45 & 7.25 \\
\hline 2 & 65 & 75 & 45 & 7.42 \\
\hline 3 & 45 & 85 & 45 & 7.49 \\
\hline 4 & 65 & 85 & 45 & 8.15 \\
\hline 5 & 45 & 75 & 75 & 8.18 \\
\hline 6 & 65 & 75 & 75 & 8.21 \\
\hline 7 & 45 & 85 & 75 & 8.34 \\
\hline 8 & 65 & 85 & 75 & 8.43 \\
\hline 9 & 45 & 80 & 60 & 8.27 \\
\hline 10 & 65 & 80 & 60 & 8.51 \\
\hline 11 & 55 & 75 & 60 & 8.25 \\
\hline 12 & 55 & 85 & 60 & 8.31 \\
\hline 13 & 55 & 80 & 45 & 8.14 \\
\hline 14 & 55 & 80 & 75 & 8.78 \\
\hline 15 & 55 & 80 & 60 & 8.71 \\
\hline 16 & 55 & 80 & 60 & 8.81 \\
\hline 17 & 55 & 80 & 60 & 8.80 \\
\hline 18 & 55 & 80 & 60 & 8.79 \\
\hline 19 & 55 & 80 & 60 & 8.84 \\
\hline 20 & 55 & 80 & 60 & 8.86 \\
\hline
\end{tabular}
was as follows: extraction time $>$ extraction temperature $>$ water-to-raw-material ratio.

Ta ble 1 - CCD and the response values for yields of flavonoids Ta b I i c a 1-CCD i iskorištenje ekstrakcije flavonoida

\begin{tabular}{|c|c|c|c|c|c|}
\hline $\begin{array}{l}\text { Source } \\
\text { Izvor }\end{array}$ & $\begin{array}{c}\text { Sum of } \\
\text { squares } \\
\text { Zbroj } \\
\text { kvadrata }\end{array}$ & $\begin{array}{l}\text { Degree } \\
\text { freedom } \\
\text { Stupanj } \\
\text { slobode }\end{array}$ & MSE & $F$ & $p$ \\
\hline model & 4.27 & 9 & 0.47 & 33.43 & $<0.0001$ \\
\hline$X_{1}$ & 0.14 & 1 & 0.14 & 9.99 & 0.0102 \\
\hline$X_{2}$ & 0.20 & 1 & 0.20 & 14.02 & 0.0038 \\
\hline$x_{3}$ & 1.22 & 1 & 1.22 & 85.89 & $<0.0001$ \\
\hline$X_{1} X_{2}$ & 0.038 & 1 & 0.038 & 2.67 & 0.1335 \\
\hline$X_{1} X_{3}$ & 0.063 & 1 & 0.063 & 4.44 & 0.0613 \\
\hline$X_{2} X_{3}$ & 0.044 & 1 & 0.044 & 3.07 & 0.1104 \\
\hline$X_{1}^{2}$ & 0.19 & 1 & 0.19 & 13.48 & 0.0043 \\
\hline$X_{2}^{2}$ & 0.38 & 1 & 0.38 & 27.07 & 0.0004 \\
\hline$X_{3}{ }^{3}$ & 0.10 & 1 & 0.10 & 7.27 & 0.0225 \\
\hline $\begin{array}{l}\text { residual } \\
\text { rezidualno }\end{array}$ & 0.14 & 10 & 0.014 & & \\
\hline $\begin{array}{c}\text { lack of fit } \\
\text { provjera } \\
\text { modela }\end{array}$ & 0.13 & 5 & 0.026 & 9.52 & 0.0136 \\
\hline $\begin{array}{l}\text { pure error } \\
\text { čista } \\
\text { pogreška }\end{array}$ & 0.013 & 5 & 0.002697 & & \\
\hline $\begin{array}{c}\text { cor. total } \\
\text { ukupno } \\
\text { korig. }\end{array}$ & 4.41 & 19 & & & \\
\hline \multicolumn{6}{|c|}{$R^{2}=0.9678 \quad R_{\mathrm{adj}}^{2}=0.9389$} \\
\hline
\end{tabular}

Table 2 - Analysis of variance for fitted quadratic polynomial model

Tabli c a 2 - Analiza varijancije odgovarajućeg kvadratnog polinoma

\section{Response surface analysis}

The relationship between independent and dependent variables was illustrated by the three-dimensional representation of the response surfaces by the model, as presented in Fig. 2 for the independent variables (the water-to-material ratio, extraction temperature, and extraction time), obtained by keeping one of the variables constant, which indicated the changes in extraction yield under different conditions. Fig. 2a shows the 3D response surfaces, the combined effect of the water-to-material ratio, and extraction temperature on the extraction yield, and it revealed that the extraction yield was minimal at low and high levels of the water-to-material ratio and extraction temperature. When water-to-material ratio was at a certain value, the extraction yield increased with the increase in extraction temperature. However, it was not significant that the increase in extraction temperature affected the extraction yield at a certain water-to-material ratio. From Fig. 2b, the results indicated that the interactions between the water-to-material ratio and extraction time were significant when the other variables were fixed at a constant. As shown in Fig. 2c, extraction temperature, extraction time displayed a quadratic effect on the response. Their interaction effect on the yield was not significant. 

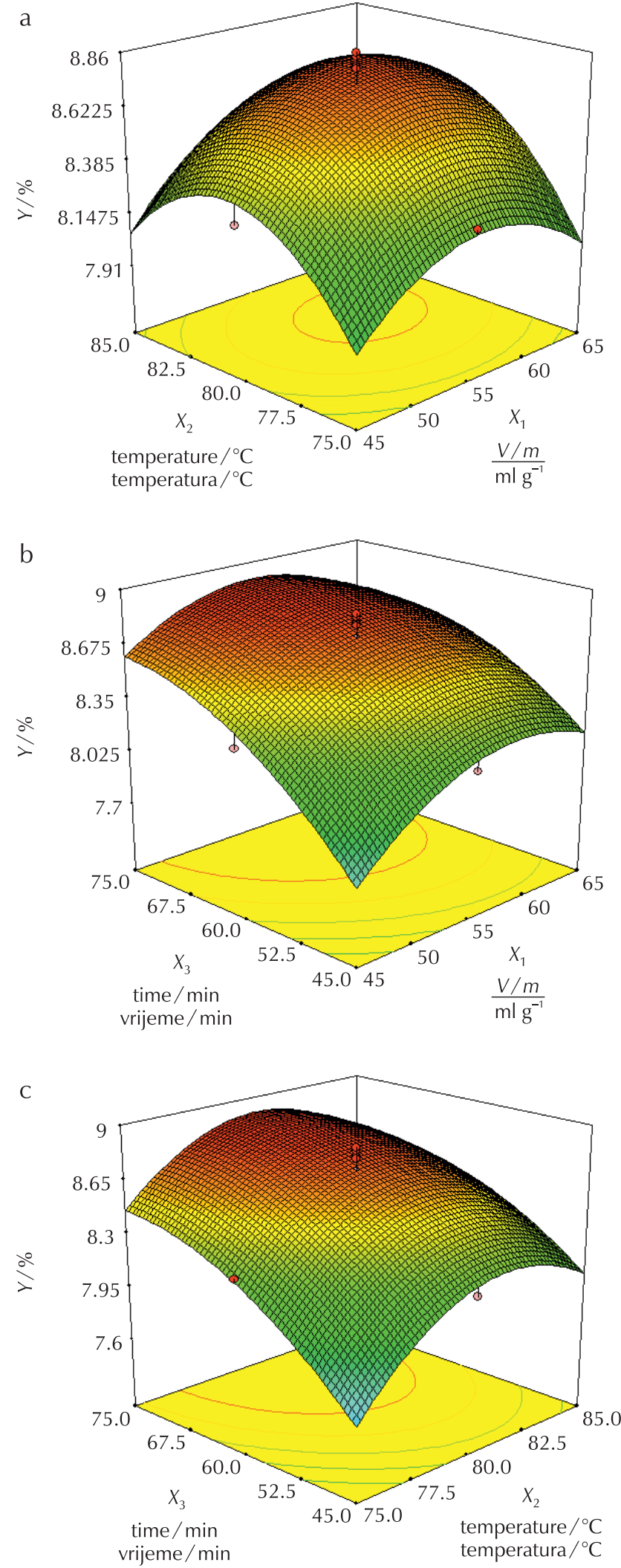

Fig. 2 - Response surface (3D) showing the effect of different extraction parameters on the yield of flavonoid extraction

SIika 2 - Trodimenzionalna odzivna površina koja prikazuje utjecaj različitih parametara na iskorištenje ekstrakcije flavonoida

\section{Optimization and verification}

The optimum condition was obtained by using DesignExpert software, and recommended as follows: water-to-material ratio of $55.96 \mathrm{ml} \mathrm{g}^{-1}$, extraction temperature $80.56{ }^{\circ} \mathrm{C}$, and extraction time 72.87 minutes. The maximum predicted yield of $8.91 \%$ was obtained under these conditions.

To validate the experimental method, the extraction conditions were adjusted according to actual production, as follows: water-to-material ratio of $55 \mathrm{ml} \mathrm{g}^{-1}$, extraction temperature $80{ }^{\circ} \mathrm{C}$, and extraction time $70 \mathrm{~min}$. The result showed that the experimental values of $8.96 \%$ were not only consistent with the predicted values, but were also better than any single factor experiments. The response model was adequate for the optimization of extraction process (Table 2), and the model of Eq. (3) was accurate.

\section{Conclusions}

RSM was applied to predict optimum conditions for extraction of flavonoid from C. tinctoria. The optimal extraction conditions were obtained as water-to-raw-material ratio of $55 \mathrm{ml} \mathrm{g}^{-1}$, extraction temperature of $80{ }^{\circ} \mathrm{C}$, and extraction time of $70 \mathrm{~min}$. Under these conditions, the average total flavonoids yield was $9.0 \pm 0.6 \%$.

This work clearly showed that the extraction of flavonoids from $C$. tinctoria could be improved by optimizing key extraction parameters (time, temperature, water-to-raw-material ratio). Therefore, this research could be useful for preparation of flavonoids based on C. tinctoria for the food and drug industries. In this paper, we chose hot water as the extraction solution rather than methanol or ethanol. The extraction yield was less than methanol or ethanol extraction. ${ }^{18}$ The main reason being to provide a foundation for the development of tea beverages. The RSM could be applied to predict optimum conditions for extraction of flavonoid from C. tinctoria.

\section{ACKNOWLEDGEMENTS}

This research was supported by the Chinese National Natural Science Foundation (No. 31060041), the Natural Science Foundation of Gansu Province (3ZS062-B25-023, 1212RJYA008) and the Teaching Research Project from Lanzhou University of Technology (JY2012045).

\section{List of symbols and abbreviations Popis simbola i kratica}

\begin{tabular}{|c|c|}
\hline$F$ & $\begin{array}{l}-F \text {-value } \\
-F \text {-vrijednost }\end{array}$ \\
\hline$m$ & $\begin{array}{l}\text { - mass of the raw material, g } \\
\text { - masa sirovog materijala, } g\end{array}$ \\
\hline$N$ & $\begin{array}{l}\text { - dilution factor } \\
\text { - faktor razrjeđenja }\end{array}$ \\
\hline$p$ & $\begin{array}{l}-p \text {-value } \\
-p \text {-vrijednost }\end{array}$ \\
\hline$R^{2}$ & $\begin{array}{l}\text { - coefficient of determination } \\
\text { - determinacijski koeficijent }\end{array}$ \\
\hline
\end{tabular}




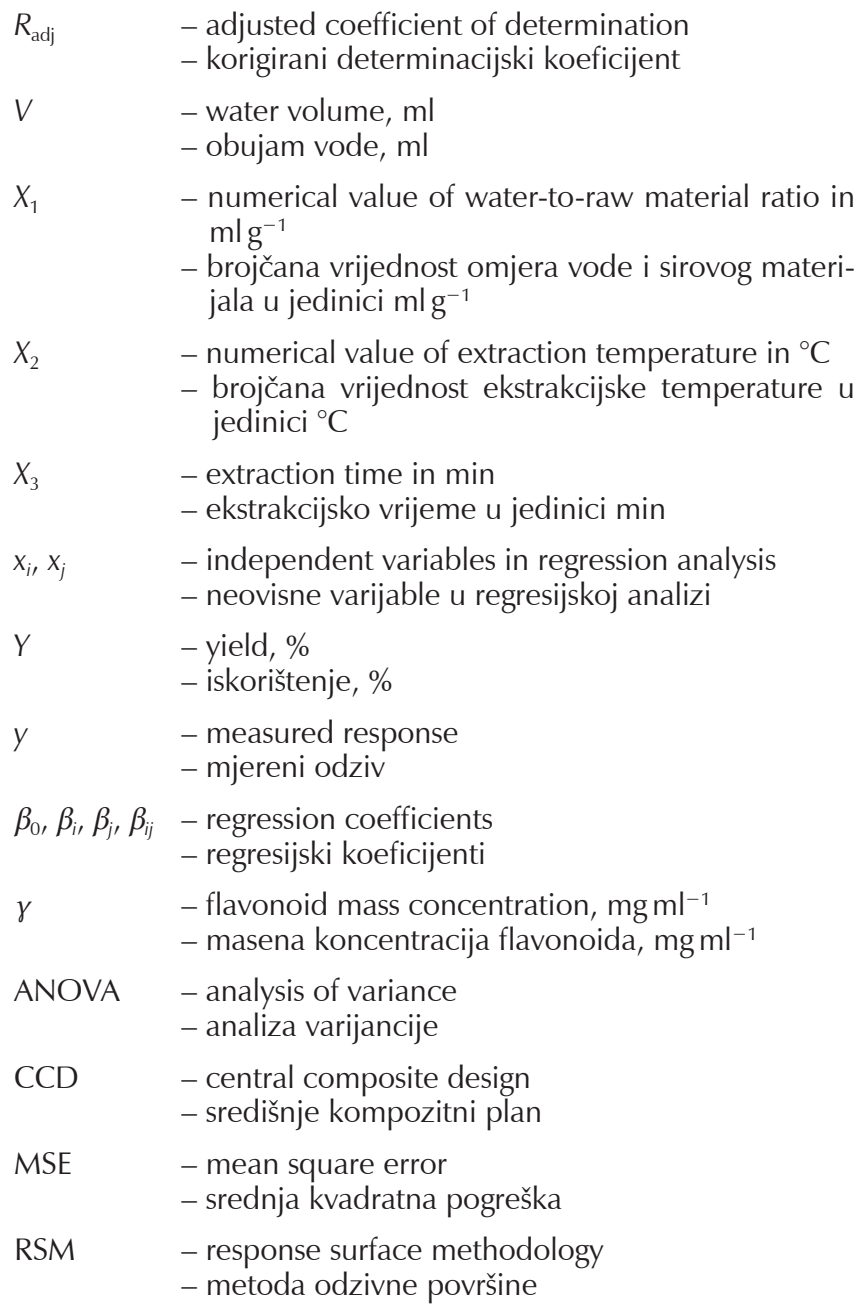

\section{References}

\section{Literatura}

1. B. Aliakbarian, A. Fathi, P. Perego, F. Dehghani, Extraction of antioxidants from winery wastes using subcritical water, Supercrit. Fluid. 65 (2012) 18-24, doi: http://dx.doi.org/10.1016/j. supflu.2012.02.022.

2. A. S. Awaad, D. J. Maitland, A. R. Donia, S. I. Alqasoumi, G. A. Soliman, Novel flavonoids with antioxidant activity from a Chenopodiaceous plant, Pharm. Biol. 50 (2012) 99-104, http://dx.doi.org/10.3109/13880209.2011.591806.

3. T. P. T. Cushnie, A. J. Lamb, Antimicrobial activity of flavonoids, Int. J. Antimicrob. Agents. 5 (2005) 343-356, doi: http://dx. doi.org/10.1016/j.ijantimicag.2005.09.002.

4. S. Hamamatsu, K. Yabe, Y. Nawa, Compositions of Anthocyanin and Other Flavonoids in Cultured Rabbiteye Blueberry (Vaccinium ashei Reade cv. Tiiblue), Food Sci. Technol. Res. 3 (2004) 239-246, doi: http://dx.doi.org/10.3136/fstr.10.239.

5. M. D. R. Santos, A. P. Vitor, J. C. Carneiro, D. S. C. Paciullo, R. C. Matos, M. A. C. Matos, Use of Ultrasound Bath in the Extraction and Quantification of Ester-Linked Phenolic Acids in
Tropical Forages, Am. J. Anal. Chem. 3 (2011) 344-351, doi: http://dx.doi.org/10.4236/ajac.2011.23042.

6. Y. Zhang, S. Shi, M. Zhao, Y. Jiang, P. Tu, A novel chalcone from Coreopsis tinctoria Nutt, Biochem. Syst. Ecol. 34 (2006) 766769, doi: http://dx.doi.org/10.1016/j.bse.2006.05.005.

7. E. J. Middleton, Effect of plant flavonoids on immune and inflammatory cell function, Adv. Exp. Med. Biol. 439 (1998) 175-182, doi: http://dx.doi.org/10.1007/978-1-4615-5335913.

8. A. H. Laghari, S. Memon, A. Nelofar, K. M. Khan, A. Yasmin, M. N. Syed, A. Aman, A New Flavanenol with Urease-Inhibition Activity Isolated from Roots of Manna Plant Camelthorn (Alhagi maurorum), J. Mol. Structure. 1-3 (2010) 65-67, doi: http:// dx.doi.org/10.1016/j.molstruc.2009.11.039.

9. H. Wei, L. Tye, E. Bresnick, D. F. Birt, Inhibitory Effect of Epigenin, a Plant Flavonoid on Epidermal Ornithine Decarboxylase and Skin Tumor Promotion in Mice, J. Cancer Res. 3 (1990) 499-502.

10. T. Dias, B. Liu, P. Jones, P. J. Houghton, Helder Mota-Filipe, A. Paulo, Cytoprotective effect of Coreopsis tinctoria extracts and flavonoids on tBHP and cytokine-induced cell injury in pancreatic MIN6 cells, J. Ethnopharmacol. 139 (2012) 485-492, doi: http://dx.doi.org/10.1016/j.jep.2011.11.038.

11. T. Dias, M. R. Bronze, P. J. Houghton, P. J. Houghton, H. Mota-Filipe, A. Paulo, The flavonoid-rich fraction of Coreopsis tinctoria promotes glucose tolerance regain through pancreatic function recovery in streptozotocin-induced glucose-intolerant rats, J. Ethnopharmacol. 132 (2010) 483-490, doi: http://dx.doi.org/10.1016/j.jep.2010.08.048.

12. X. Y. Zhu, Y. L. Mang, J. Xie, P. Wang, W. K. Su, Response surface optimization of mechanochemical assisted extraction of flavonoids and terpene trilactones from Ginkgo leaves, Ind. Crops Prod. 34 (2011) 1041-1052, doi: http://dx.doi.org/10.1016/j. indcrop.2011.03.013.

13. G. Y. Pan, G. Y. Yu, C.H. Zhu, J. I. Qiao, Optimization of ultrasound-assisted extraction (UAE) of flavonoids compounds (FC) from hawthorn seed (HS), Ultrason. Sonochem. 19 (2012) 486490, doi: http://dx.doi.org/10.1016/j.ultsonch.2011.11.006.

14. W. H. Xiao, L. J. Han, B. Shi, Optimization of microwave-assisted extraction of flavonoid from Radix Astragali using response surface methodology, Sep. Sci. Technol. 43 (2008) 671-681, doi: http://dx.doi.org/10.1080/01496390701812509.

15. Z. L. Sheng, P. F. Wan, C. L. Dong, Y. H. Li, Optimization of total flavonoids content extracted from Flos Populi using response surface methodology, Ind. Crops Prod. 43 (2013) 778-786, doi: http://dx.doi.org/10.1016/j.indcrop.2012.08.020.

16. Q. Xu, Y. Y. Shen, H. F. Wang, N. Zhang, S. Xua, L. Zhang, Application of response surface methodology to optimise extraction of flavonoids from fructus sophorae, Food chem. 138 (2013) 2122-2129, doi: http://dx.doi.org/10.1016/j.foodchem.2012.11.099.

17. Q. P. Wu, Z. J. Wang, L. Y. Tang, M. H. Fu, Y. He, A New Flavonoid Glucoside from Cassia angustifolia, Chin. Chem. Lett. 3 (2009) 320-321, doi: http://dx.doi.org/10.1016/j.cclet.2008.12.003.

18. Y. Wang, Y. L. Zhang, S. Aytulun, Determination on total flavonoids content in Kunlun Chrysanthemum by visible spectrophotometry method, J. Xinjiang Med. Univer. 34 (2011) 817-819. 


\title{
SAŽETAK
}

Optimizacija metodom odzivne površine ekstrakcije ukupnih flavonoida iz Coreopsis tinctoria Nutt.

\author{
X. F. Liu, L. Liu, Y. G. Wang, "F. F. Leng, S. W. Wang i Y. C. Li
}

Metodom odzivne površine (RSM) utvrđeni su optimalni uvjeti za ekstrakciju flavonoida iz Coreopsis tinctoria. Središnje kompozitni plan (CCD) primijenjen je za praćenje utjecaja temperature, vremena te omjera vode i sirovog materijala na prinos ukupnih flavonoida. Optimalni ekstrakcijski uvjeti su omjer vode i materijala $55 \mathrm{ml} \mathrm{g}^{-1}$, temperatura $80{ }^{\circ} \mathrm{C}$ i ekstrakcijsko vrijeme $70 \mathrm{~min}$. Pri tim uvjetima prosječno iskorištenje ekstrakcije ukupnih flavonoida u odnosu na sirovi materijal bilo je 9,0 $00.6 \%$, što se slaže s predviđenom vrijednosti 8,9 \%. Ekstrakcija je uspješno primijenjena za ekstrakciju ukupnih flavonoida iz C. tinctoria.

School of Life Science and Engineering

Prispjelo 17. kolovoza 2013. Lanzhou University of Technology 730050 Lanzhou Prihvaćeno 17. prosinca 2013.

Kina 